\title{
Alan Bollard, A Few Hares to Chase: The Life and Economics of Bill Phillips
}

(Auckland University Press, Auckland, 2016)

\section{Reviewed by Selwyn Cornish ${ }^{1}$}

Thomas Carlyle called economics 'the dismal science'. Some aspects of economics may fairly be described as 'dismal'. But it would be a particularly harsh judgement - and an inaccurate one - if that description were applied to the discipline as a whole. If the increasing size of biographies (and autobiographies) of economists is used as the measure, it would appear that economists are anything but dismal. Take John Maynard Keynes, for example. Robert Skidelsky's life of Keynes covers three volumes, totalling some 1,758 pages; Donald Moggridge's single-volume biography of Keynes is 941 pages in length. And Keynes was only 62 when he died! Susan Howson's life of Lionel Robbins is 1,161 pages; Peter Groenewegen's life of Alfred Marshall is 864 pages; and Marjorie Harper's biography of Sir Douglas Copland, The Australian National University's first Vice-Chancellor, is 548 pages. These economists must have been doing some interesting things to warrant such prolonged engagement by their biographers - and most assuredly they did.

Bill Phillips, the author of the eponymous 'Phillips Curve', and the subject of A Few Hares to Chase, was many things: modest, sober, unpretentious, imaginative, inquisitive and a genius; but rarely, if ever, dismal. Alan Bollard, the former Governor of the Reserve Bank of New Zealand, and the author of this biography of Phillips, refers to his subject as 'remarkable'. And so he was. Here was a man born on a small dairy farm in 1914 in an obscure part of New Zealand, who went to local schools, qualified as an electrician after serving an apprenticeship with a local hydro-electric authority, worked for some years in the back blocks of New South Wales and Queensland, crossed Asia and Europe

1 Research School of Economics, College of Business and Economics, The Australian National University; selwyn.cornish@anu.edu.au. 
on the trans-Siberian railway before the outbreak of the Second World War, enlisted in the RAF in London, was captured by the Japanese while trying to escape at the fall of Singapore, spent the rest of the war in appalling conditions in prisoner-of-war camps at various locations on the island of Java, returned to London via New Zealand after the war, enrolled for a degree in sociology at the London School of Economics (LSE), successfully completed a PhD in economics at LSE, was appointed to one of the most prestigious chairs of economics in the world (the Tooke chair, which had previously been occupied by Friedrich Hayek), wrote one of the most cited articles in economics, accepted a research chair in economics at ANU and died in 1975 at the of 60, lecturing, at the University of Auckland, until the day before he died.

Bollard has written a superb biography of the man, at once concise, elegant and extensively researched. The essential biographical details of Phillips's life are told against the backdrop of local and world history, with the contemporary events linked to the personal story in such a way that the two appear to be seamless. To achieve this feat successfully without appearing to be contrived is an exceptional skill, adding as it does to the pleasure of reading the book.

During his undergraduate studies in sociology - for which he showed little interest or aptitude, and obtaining a poor third as a result - Phillips began to consider economics. With the assistance of another returned serviceman who was studying at LSE for an economics degree - Walter Newlyn - Phillips built a hydro-mechanical model of a Keynesian macro-economy, using perspex tanks and tubes through which water was pumped. The model, known commonly by the acronym MONIAC (Monetary National Income Automatic Computer), which went through a number of increasingly complex versions, demonstrated what might happen to output and employment if aggregate demand were to change or policy was altered. Senior economists at LSE, including James Meade and Lionel Robbins, quickly saw its potential as a teaching device and orders soon poured in from universities (the University of Melbourne acquired one), governments and central banks. Bollard suggests that Phillips may have derived the idea of demonstrating the working of a monetary economy by means of a hydraulic model from a diagram in Kenneth Boulding's well-known economics textbook.

Consequent upon its successful application, Phillips was offered and accepted an assistant lectureship in economics at LSE and, following an article explaining the uses of the model in Economica, he was permitted to enrol for a $\mathrm{PhD}$, supervised by James Meade and James Durbin. Several articles followed and he was elevated to a lectureship. On the completion of his doctorate he was appointed Reader. Following his famous article of 1958 featuring the 'Phillips Curve', he was offered the Tooke chair. It had taken him less than 10 years from 
the third-class degree in sociology to the occupancy of the most prestigious chair in economics at one of the world's greatest centres for the study of economics. This, as Bollard rightly asserts, was 'remarkable'.

Phillips's research output was directed predominantly to issues of stabilisation using econometrics and drawing upon elements of control theory. He contended that 'economists could understand and promote stability, but they had much less to offer to development policies', holding as he did that 'economists do not really know very much about economic development'. He was particularly interested in ideas and mechanisms developed and applied in engineering, whereby potential faults or sources of volatility could be quickly corrected - or controlled - by counteracting forces. He regarded Keynes's work as satisfactory perhaps for dealing with singular depressions, but the more pressing problem in the post-Second World War era was how to deal with continuing fluctuations in economic activity. Though Phillips himself always claimed that 'all I did was set a few hares running for others to chase', Bollard argues that Phillips:

was a man of original ideas, whose restless mind leapt ahead, while it was often left to others to develop the full implications of the work, and to receive the kudos for them.

He suggests that as many as a 'dozen Nobel Laureates have owed some sort of debt' to Phillips. This seems to be a not uncommon experience for antipodean economists - Trevor Swan comes readily to mind.

What of the 1958 article and the 'Phillips Curve'? An entire chapter is devoted to the origins of the article and its subsequent life. The problem of retaining wage and price stability as activity gains momentum was highly relevant to Phillips's research agenda. It seems that he was encouraged to write something on the subject by his LSE colleague Henry Phelps Brown, a labour economist. Devoting a 'wet weekend' to plotting long-run data on wages and employment by hand on graph paper, the important conclusion was that inflation did not simply take off at full employment, as commonly believed. As Bollard rightly points out, the Phillips Curve 'was a distinct improvement on the old textbook treatment, with its sharp dichotomy between stable prices and inflation'. Further, according to Bollard:

it allowed economists to go beyond the crude assumption of wage rigidity. The Curve provided a way to consider how wages could adjust to excess supply that was slow to react to excess demand.

It was, of course, a fallacy to regard the Phillips Curve as a representation of Keynes's economics; one only had to read Chapter 19 of The General Theory (headed 'Changes in Money Wages') to know that Keynes believed that wages - 
and hence prices - would commence to rise some distance before full employment was reached (which Keynes himself regarded as occurring when unemployment reached $4-5$ per cent).

In 1967, Phillips decided to leave the LSE for a professorial appointment in the Department of Economics at the ANU Research School of Social Sciences. ${ }^{2}$ The reasons why he left London have never been entirely clear. Bollard rehearses the usual reasons - the student problems at LSE, the problems of rush-hour commuting 'on the congested and erratic Northern line of the Underground (the so-called "misery line")', the 1967 sterling crisis that led to the devaluation of the British currency, a desire to be closer to his New Zealand roots, concerns about the upbringing of his young family in 'a crowded and occasionally violent city', recurring health problems arising from his wartime incarceration, and the desire to embark on a new research agenda involving the study of the modern Chinese economy. Bollard does not discount any of these reasons but he proposes another one. There is the possibility that Phillips had become increasingly worried about an intellectual problem associated with much of his econometric work - the identification problem - a problem that was pointed out to him by younger LSE statisticians, including Denis Sargan. This was putting the results of his work at risk. 'There were signs', Bollard writes, that Phillips was:

becoming intellectually frustrated; he mentioned his concern that he was not keeping up with the literature. In particular he remained worried that all his hard pioneering work estimating how to regulate for economic stability was at risk from the frustrating possibility for technical misidentification.

This frustration, however, was to continue at ANU. Ted Hannan, The Australian National University's world-renowned mathematical statistician and econometrician, had opposed Phillips's ANU appointment and the two men were often observed around the campus engaged in heated debate. Bollard suggests that the 'relationship with Hannan in Canberra was reminiscent of that with Sargan in London'. It is perhaps not surprising that, within a year of his arrival in Canberra, Phillips was writing to his former mentor and PhD supervisor, James Meade - now Professor of Political Economy at Cambridge - asking whether there was the possibility of a research appointment at Cambridge. But before a decision could be made, Phillips suffered a massive stroke, effectively ending his academic career. Instead of returning to the UK, he retired to Auckland, where another stroke resulted in his premature death.

2 See Cornish, S. and Millmow, A. 2016, 'A.W.H. Phillips and Australia', History of Economics Review 63(1): 2-20. 
At ANU, Phillips scarcely had time to settle in before his illness. He managed, however, to present a paper to a departmental seminar. The paper is of some interest because it revealed his position on aspects of economic policy. Hitherto his attitude had been that:

the first priority for an academic economist should be to get on with the difficult, painful and demanding job of trying to find out more how the economy works and that he should resist the temptation to divert his limited time and energy to general debate on policy issue.

But he was now prepared to offer some policy advice. He thought that adjustment of taxes was the most suitable instrument for short-term management of aggregate demand. In contrast, variations in government expenditure were likely to be too slow in their application and effect. He particularly favoured the idea of greater flexibility in the use of fiscal policy by adjusting taxes in various ways within financial years rather than waiting for the annual government budget. As to monetary policy, while it might be able to provide modest support in the control of fluctuations, its more significant role was to provide for longer-term balance between the supply of savings and the demand for investment. On the question of external balance, Phillips supported flexible exchange rates; this, he argued, should be the normal method for preserving external balance rather than something to be used simply as a last resort.

Regarding his work at ANU on China, Bollard points out that this was not a new interest. In fact, he had first developed an enthusiasm for China while working on hydro-electric schemes in New Zealand. When travelling through Manchuria in the late 1930s he had empathised with the Chinese struggle against the Japanese occupation. And in the POW camps he sympathised with Chinese prisoners and learnt Mandarin from them. In London he attended seminars at the School of Oriental and African Studies and at the Modern China seminars at University College. At ANU he collected material on China and engaged a research associate fluent in Mandarin, who assisted him in the translation of Chinese policy papers and other research material. A draft paper was prepared that included an analysis of the state of the Chinese economy at the time of the Communist takeover, an account of the country's development plans since 1949, and there were sections on postwar land consolidation, promotion of industrial development, the collectivisation of agriculture and the Great Leap Forward. But even with this background and preliminary work, Bollard is puzzled by Phillips's determination to work on the modern Chinese economy, pointing out that his earlier work was on economic stabilisation and he had questioned whether economists had much to offer on questions of development. 
Perhaps it should be left to those who knew Phillips best to sum up the man and his standing among his peers. Here are testimonials from three of his closest LSE colleagues. To Lionel Robbins, Phillips at the time of his departure for ANU was one of LSE's 'most outstanding members ... an economist of international frame still at the height of his powers'. Henry Phelps Brown wrote that:

to know him was to like him. He was friendly, full of quiet enthusiasm for whatever ideas he was pursuing at the time, and without the slightest trace of self-importance or pomposity.

James Meade wrote that Phillips:

was a most remarkable man, extremely simple and straightforward. He was a real genius in that he always saw the main point at issue, spoke of it with the utmost directness and in the simplest possible language ... he was an unaffected, undemonstrative, true and lovable friend as well as being an unaffected, undemonstrative, commonsensical and versatile genius.

Readers of this fine biography will no doubt reach similar conclusions. 
This text is taken from Agenda, Volume 23 - Number 1, 2016, edited by William Coleman, published 2016 by ANU Press, The Australian National University, Canberra, Australia. 